\title{
A Comparison of Actual Graft Weight and Estimated Graft Volume Calculated with New Software Used for Anatomical and Volumetric Analysis of the Liver with Computed Tomography in Living Liver Donors
}

\author{
Canlı Karaciğer Vericilerinde Karaciğerin Bilgisayarlı Tomografi ile Anatomik \\ ve Hacimsel Analizi için Kullanılan Yeni Bir Yazılım Programı ile Hesaplanan \\ Tahmini Greft Hacmi ile Gerçek Greft Ağırlığının Karşılaştırılması
}

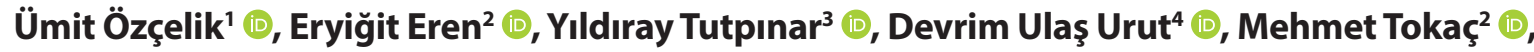 Ayhan Dinçkan² (D)}

\footnotetext{
'Department of General Surgery, İstanbul Aydın University Training and Research Hospital, Küçükçekmece, İstanbul, Turkey 2Department of General Surgery, İstinye University Training and Research Hospital, Esenyurt, İstanbul, Turkey ${ }^{3}$ Department of Radiology, İstinye University Training and Research Hospital, Esenyurt, Istanbul, Turkey 4Department of Radiology, İstanbul Aydın University Training and Research Hospital, Küçükçekmece, İstanbul, Turkey
}

ORCID ID: Ü.Ö. 0000-0003-1073-2494; E.E. 0000-0001-6705-4095; Y.T. 0000-0001-9445-6604; D.U.U. 0000-0003-4763-8645; M.T. 0000-0002-7278-0937; A.D. 0000-0003-1395-333X

Cite this article as: Özçelik Ü, Eren E, Tutpınar Y, Urut DU, Tokaç M, Dinçkan A. A comparison of actual graft weight and estimated graft volume calculated with new software used for anatomical and volumetric analysis of the liver with computed tomography in living liver donors. Experimed 2021; 11(2): 96-101.

\begin{abstract}
Objective: In the living donor liver transplantation (LDLT) context, accurate estimation of the graft weight to recipient weight ratio (GRWR) and future donor liver remnant volume by pre-operative volumetric analysis is very important. We aimed to compare the estimated graft volume (EGV) calculated with the LiverVision ${ }^{\circledR}$ software with the actual graft weight (AGW) measured in the back-table in this study.
\end{abstract}

Material and Method: Patients who underwent right lobe LDLT and liver donors between 01.01.2018-30.05.2020 were retrospectively evaluated. Demographic data, body mass index, EGV, AGW and GRWR were recorded. Linear regression analysis, Pearson correlation coefficient and Bland-Altman plots were utilized for evaluation of the relationships between continuous variables.

Results: A total of 108 liver donors were included in the study. The mean age of the donors was $32.6 \pm 8.8$ years and mean EGV was $902.5 \pm 147.1 \mathrm{~mL}$ for all donors. The mean AGW was $890.6 \pm 145.9$ $\mathrm{g}$ for all donors. A significant correlation was found between EGV and AGW for all donors $(r=0.856, p<0.001)$. The mean difference between EGV and AGW was 11.9 \pm 78.5 for all donors. 105 of the 108

\section{öz}

Amaç: Canlı vericili karaciğer naklinde, alıcıda greftin alıc ağılığına oranının (GRWR) ve vericide ameliyat sonrası kalacak karaciğer hacminin ameliyat öncesi hacimsel analizle doğru tahmin edilmesi çok önemlidir. Bu çalışma ile karaciğer vericilerinde karaciğerin anatomik ve hacimsel analizinin yapılması için kullandığımız LiverVision ${ }^{\circledast}$ programı ile hesaplanmış tahmini sağ lob greft hacimlerinin (EGV) ameliyat sırasında arka-masada (back-table) ölçülen gerçek greft ağırlığı (AGW) ile karşılaştııılması amaçlanmıştır.

Gereç ve Yöntem: Çalışmamızda 01.01.2018-30.05.2020 tarihleri arasında canlı vericiden sağ lob karaciğer nakli yapılmış olan hastalar ve vericileri retrospektif olarak incelenmiştir. Hastaların demografik bulguları, vücut kitle indeksi, EGV, AGW ve GRWR kayıt altına alınmıştır. Sürekli değişkenler arasındaki ilişkiler, Pearson korelasyon katsayısı, doğrusal regresyon analizi ve Bland Altman grafikleri ile değerlendirilmiştir.

Bulgular: Ortalama yaşı 32,6 $\pm 8,8$ yıl olan toplam 108 karaciğer vericisi çalışmaya dâhil edilmiştir. Ortalama EGV tüm vericiler için, $902,5 \pm 147,1 \mathrm{~mL}$ iken, ortalama AGW tüm vericiler için 890,6 $\pm 145,9$ $\mathrm{g}$ olarak hesaplanmıştır. Tüm vericiler için EGV ile AGW arasında an- 
(97.2\%) measurements were within the $95 \%$ ranges of agreement between EGV and AGW according to the Bland-Altman plot. According to the regression model created to calculate the AGW, the formula AGW $(\mathrm{g})=0.85 \times \mathrm{xGV}(\mathrm{mL})+124.5$ was obtained $\left(\mathrm{r}^{2}=0.732, \mathrm{p}<0.001\right)$.

Conclusion: The liver volumes of the donors were successfully estimated with computed tomography (CT) with the newly developed Turkish semi-automatic LiverVision ${ }^{\circledR}$ software.

Keywords: Liver transplantation, living liver donor, estimated graft volume; actual graft weight, software

\section{INTRODUCTION}

The best treatment modality for end-stage liver failure is liver transplantation. In countries where deceased donor organ donation rates are low, as in Turkey, cadaveric graft waiting lists are gradually increasing in length and some of the patients unfortunately die while they are on the waiting list. Liver transplantation from a living donor can be the only option for these patients who do not have the chance of cadaveric liver transplantation. Liver transplantation requires a detailed examination of the donor and recipient. This examination includes an evaluation of the liver anatomy, parenchymal and vascular structure, and donor liver volume. In living donor liver transplantation (LDLT), in order to perform a safe and successful surgery for both donor and recipient, liver volumetric analysis of the donor before the operation is very important for predicting the graft weight to recipient weight ratio (GRWR) and residual liver volume. The weight of the liver is approximately $2 \%$ of the body weight. The weight of a liver graft which will be sufficient to meet the metabolic needs of the recipient body, has to be $40-50 \%$ of the recipient's liver weight, which corresponds to approximately $0.8-1 \%$ of the recipient's body weight (1). Therefore, it is recommended that the GRWR be not less than $0.8 \%$ for a successful liver transplant $(1,2)$. Small for size syndrome is more likely to occur if the GRWR is below $0.8 \%$ (2). This syndrome manifests itself with coagulopathy, long-term cholestasis, ascites and graft failure (2) For the safety of the living donor, the remnant liver volume must be at least $30 \%$ (2).

Computed tomography (CT) is recognized worldwide as the best imaging modality used in the preoperative evaluation of liver volume. In the past, while liver volume measurements with CT were made 2-dimensionally and manually, today there are many examples of 3-dimensional (3D) software that have been used for this purpose. After Van Thiel et al. showed in 1985 that there is a well-nigh relationship between water volume and liver weight at $25^{\circ} \mathrm{C}$, the volume of the liver began to be converted to one to one liver weight ( $1 \mathrm{~mL}=1 \mathrm{~g}$ ) (3). Although the difference between the estimated graft volume (EGV) and actual graft weight (AGW) has decreased as software programs have developed, in many cases, the actual graft weight is determined to be lower than the estimated graft volume. Due to this, it has been suggested that the calculations made by Van Thiel et al. were derived from cirrhotic livers and the density of non-cirrhotic livers is lower $(1,4-6)$. Dehydration because of lamlı bir korelasyon olduğu saptanmıştır $(r=0,856, p<0,001)$. Bland-Altman metoduna göre 108 ölçümün 105'inde $(\% 97,2)$ EGV, AGW ile \%95 güven aralığı içerisinde saptanmıştır. AGW'yi hesaplamak için oluşturulan regresyon modeline göre $\mathrm{AGW}(\mathrm{g})=0,85 \times \mathrm{xGV}(\mathrm{mL})+124,5$ formülü elde edilmiştir $\left(r^{2}=0,732, p<0,001\right)$.

Sonuç: Yeni geliştirilmiş Türk yapımı yarı otomatik LiverVision ${ }^{\circledR}$ yazılımı ile bilgisayarlı tomografi (BT) ile vericilerin karaciğer hacimleri başarılı bir şekilde tahmin edilebilmektedir.

Anahtar Kelimeler: Karaciğer nakli, canlı karaciğer vericisi, tahmini greft hacmi; gerçek greft ağırlığı, yazılım programı

preservative solutions and differences in the plane of division of the liver parenchyma are other suspected causes of volume-weight mismatch in the liver graft (6).

We used a new semi-automatic CT volumetry software called LiverVision $^{\circledast}$ (Medivizyon, Ankara, Turkey) for anatomical and volumetric analysis of the liver in our liver donors. The purpose of our study is to compare the estimated right lobe graft volumes calculated with the LiverVision ${ }^{\circledR}$ software with the actual liver graft weight.

\section{MATERIAL AND METHOD}

Patients who had undergone living related right lobe liver transplantation in Istanbul Aydın University Hospital and Istinye University Hospital between 01.01.2018-30.05.2020 and their donors were retrospectively evaluated in this study. The Institutional Review Board of Istanbul Aydın University (IRB approval number: 2020/313) approved the study protocol. The demographic data of the patients, body mass index (BMI), EGV calculated by LiverVision ${ }^{\circledR}$ software, AGW measured in the operation theatre and GRWR were recorded.

Preoperative CT imaging of all liver donors was performed in Istinye University Hospital Radiology Department with a multidetector (Philips Ingenuity 128, Philips Healthcare, The Netherlands) computed tomography device. Following the precontrast scanning, $120-150 \mathrm{~mL}$ of contrast agent was injected and a dynamic triphasic (arterial, portal and hepatic phase) hepatic $\mathrm{CT}$ at $3 \mathrm{~mm}$ slice thickness was performed. A senior radiologist (Y.T.) measured the liver volumes using LiverVision ${ }^{\circledR} 3 \mathrm{D}$ semi-automatic volumetric software. The estimated amount of blood in the hepatic veins and portal venous system was also calculated with this software. An illustration of the 3D liver image and liver volume calculation from the software is shown in Figure 1.

Blood-free actual graft weight was measured in the donor before the graft was perfused with preservative solution using a digital weight scale after removing the right lobe graft and draining the blood.

\section{Statistical Analysis}

The Shapiro-Wilk test was used to determine the conformity of continuous variables to the normal distribution. Levene's test was used to analyze the homogeneity of variances. The Student's t test was used to compare the mean of two inde- 


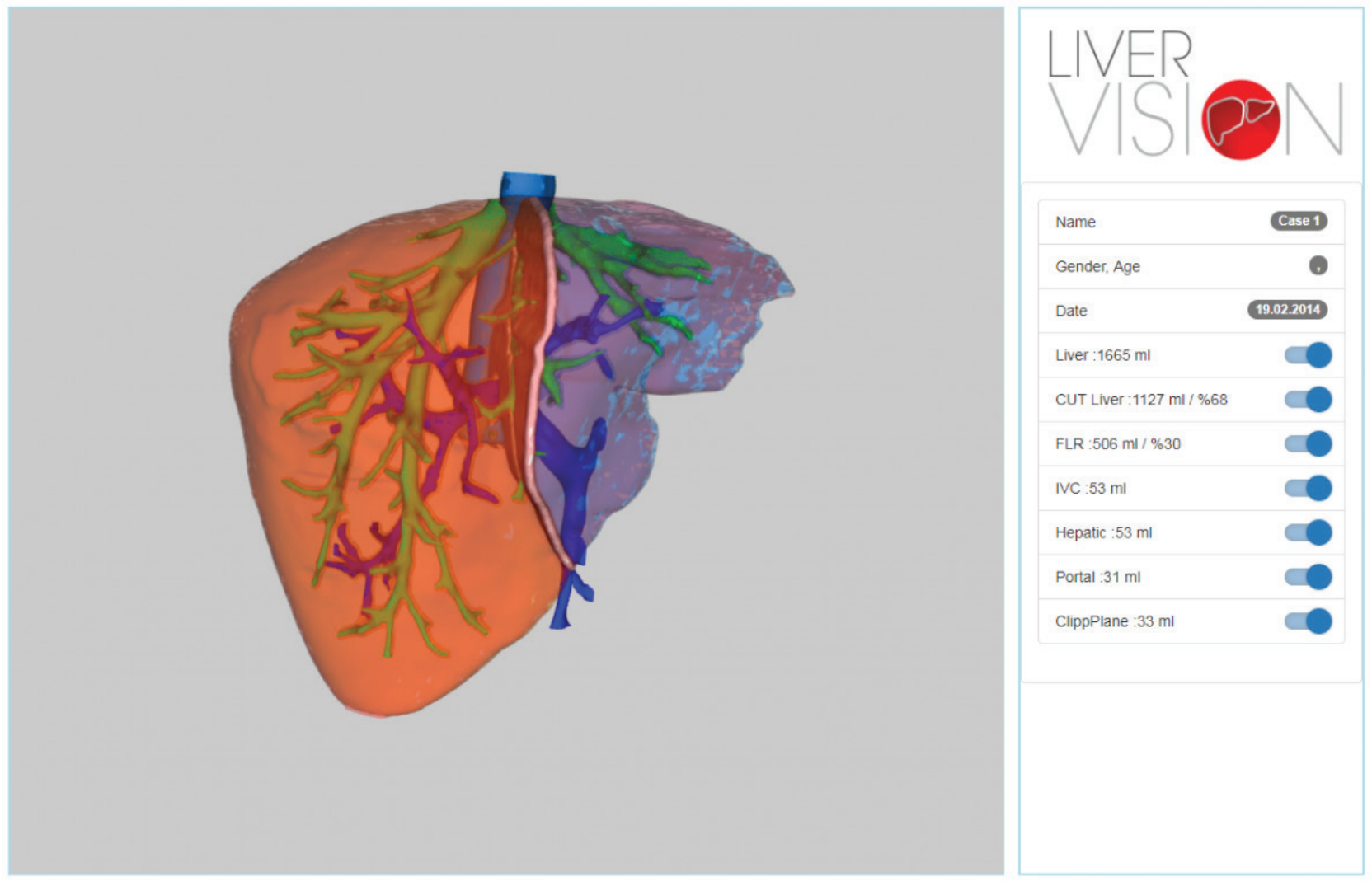

Figure 1. Illustration of 3D liver and volume calculation provided by LiverVision @ program (image taken from LiverVision.org).

pendent groups where the assumptions of the parametric tests were met. The Mann-Whitney $U$ test was utilized to compare the mean of two independent groups for variables that were determined as not meeting the prerequisites of the parametric tests. Linear regression analysis, Pearson correlation coefficient and Bland Altman plots were utilized for the evaluation of the relationships between continuous variables. A value of $p<0.05$ was accepted as statistically significant. Statistical Package for the Social Sciences (SPSS) software for Windows version 19.0 (IBM, Armonk, New York, United States) was used for the analysis of the data set.

\section{RESULTS}

A total of 108 liver donors were included in this study. Their mean age was $32.6 \pm 8.8$ years (range; $18-55)$. $73(67.6 \%)$ of the donors were male and their mean age was $31.3 \pm 8.6$ years (range; 18-55). 35 (32.4\%) of the donors were female and their mean age was $35.3 \pm 8.6$ years (range; 18-52). The overall mean body mass index was $25.6 \pm 3.5 \mathrm{~kg} / \mathrm{m}^{2}$ (range; 18.1-33.9) for all donors, while it was $25.3 \pm 3.3 \mathrm{~kg} / \mathrm{m}^{2}$ (range; 18.1-33.2) for men and $26.3 \pm 3.7 \mathrm{~kg} / \mathrm{m}^{2}$ (range; 20-33.9) for women. While there was no significant difference between men and women in terms of BMI $(p=0.159)$, there was a significant difference regarding age $(p=0.026)$. The mean estimated graft volume calculated by CT was $902.5 \pm 147.1 \mathrm{~mL}$ (range; 630-1305) for all donors, while it was $926.4 \pm 152.8 \mathrm{~mL}$ (range; 641-1305) for men and $852.5 \pm 121.7 \mathrm{~mL}$ (range; 630-1180) for women. The mean estimated graft volume of men was significantly higher than that of women $(p=0.014)$. For all donors, positive correlations were observed between EGV and height $(r=0.290, p<0.01)$, between EGV and body weight $(r=0.600, p<0.001)$, and between EGV and BMI $(r=0.384, p<0.001)$.

The mean actual graft weight was $890.6 \pm 145.9 \mathrm{~g}$ (range; 6001360) for all donors, while it was $911.7 \pm 154.2 \mathrm{~g}$ (range; 6001360) for men and $846.4 \pm 116.8 \mathrm{~g}$ (range, 680-1300) for women. The mean actual graft weight of men was significantly higher than that of women $(p=0.018)$. For all donors, there were positive correlations between AGW and height $(r=0.260, p<0.01)$, between AGW and body weight $(r=0.594, p<0.001)$ and between AGW and BMI $(r=0.403, p<0.001)$.

For all donors, there was a positive correlation between EGV and AGW ( $r=0.856, p<0.001)$. This correlation was stronger in men $(r=0.883, p<0.001)$, while it was slightly weaker in women $(r=0.728, p<0.001)$. The mean difference between EGV and AGW was $11.9 \pm 78.5$ (range; -280 to +267 ) for all donors, while it was $14.4 \pm 74.1$ (range; -280 to +202 ) in men and $6.7 \pm 87.7$ (range; -261 to +267 ) in women. No significant difference was detected between men and women regarding the difference between EGV and AGW ( $p=0.568)$. 
Table 1. Demographic and clinical data of patients.

\begin{tabular}{lcccc}
\hline Donors & Men & Women & Total & p value \\
\hline Patient number & 73 & 35 & 108 & \\
\hline Mean age (years) & $31.3 \pm 8.6$ & $35.3 \pm 8.6$ & $32.6 \pm 8.8$ & 0.026 \\
\hline BMI (kg/m $)$ & $25.3 \pm 3.3$ & $26.3 \pm 3.7$ & $25.6 \pm 3.5$ & 0.159 \\
\hline Mean EGV (mL) & $926.4 \pm 152.8$ & $852.5 \pm 121.7$ & $902.5 \pm 147.1$ & 0.014 \\
\hline Mean AGW (g) & $911.7 \pm 154.2$ & $846.4 \pm 116.8$ & $890.6 \pm 145.9$ & 0.018 \\
\hline Mean difference between EGV and AGW & $14.4 \pm 74.1$ & $6.7 \pm 87.7$ & $11.9 \pm 78.5$ & 0.568 \\
\hline Mean GRWR (\%) & $1.23 \pm 0.38$ & $1.2 \pm 0.26$ & $1.22 \pm 0.35$ & 0.602 \\
\hline
\end{tabular}

According to the Bland-Altman method, 105 (97.2\%) of the 108 measurements were within the $95 \%$ ranges of agreement between EGV and AGW. In only one of 73 male donors (1.3\%), EGV was found outside the $95 \%$ ranges of agreement, while in two of 35 female donors (5.7\%), EGV was found outside the $95 \%$ ranges of agreement.

The mean GRWR was $1.22 \pm 0.35 \%$ (range; $0.73-2.4$ ) for all patients, while it was $1.23 \pm 0.38 \%$ (range; $0.73-2.4$ ) for men and $1.2 \pm 0.26 \%$ (range, $0.85-2$ ) for women. No significant difference detected between men and women in terms of GRWR $(p=0.602)$.

In 78 patients (72.2\%), GRWR was found to be $1 \%$ and above, while in $30(27.8 \%)$ patients GRWR was found to be less than $1 \%$. In 50 (68.5\%) of the 73 male patients, GRWR was found to be $1 \%$ and above, while in 23 (31.5\%) patients GRWR was found to be less than $1 \%$. In 28 (80\%) of the 35 female patients, GRWR was found to be $1 \%$ and above, while in $7(20 \%)$ patients GRWR was found to be below 1\%. The mean difference between EGV and AGW was 7.6 \pm 85.4 (range; -280 to +267 ) for those with a GRWR of $1 \%$ and above, while it was $23 \pm 56.4$ (range; -108 to +171 ) for those with a GRWR of less than $1 \%$. No significant difference was detected between the two groups ( $p=0.265)$. In three (3.8\%) of the 78 donors with a GRWR 1\% and above, EGV was found outside the $95 \%$ ranges of agreement, while EGV was found within the $95 \%$ ranges of agreement in all 30 donors with GRWR of less than $1 \%$.

According to the regression model created to calculate the actual graft weight (AGW) using EGV, the formula AGW $(\mathrm{g})=0.85$ $x \operatorname{EGV}(\mathrm{mL})+124.5$ was obtained $\left(r^{2}=0.732, p<0.001\right)$.

The demographic data of the donors, mean estimated graft volume, mean actual graft weight, mean difference between EGV and AGW, and mean GRWR are shown in Table 1.

\section{DISCUSSION}

Due to the low number of cadaveric donors, most of the liver transplants performed in Turkey consist of living related liver transplants. The most important factor affecting the surgical planning, postoperative morbidity and mortality in the LDLT setting is the accurate preoperative estimation of donor liver volume. Overestimation or underestimation of remnant liver volume in the donor may lead to changing the surgical resection plan, or even eliminating the donor due to insufficient liver volume and canceling the surgery. Many manual and automatic volume calculation methods were developed after Heymsfield et al. defined liver volume calculation for the first time in 1979 (7). Many organ transplant centers have started to use 3D CT volumetry software with developing technology due to faster results and smaller error margin. Although calculating preoperative liver graft volume by volumetric analysis has an acceptable accuracy level in predicting actual liver volume before surgery, it is controversial that one milliliter of liver equated to one gram of liver tissue (8-10). This equation has been criticized for being based on measurements made from cirrhotic livers $(1,4)$. Some studies have revealed that the error rate in weight estimation with $\mathrm{CT}$ volumetry ranges from $\pm 5 \%$ to $\pm 20 \%$ (11). Differences in the liver density, the amount of blood in the liver, variations in tomography machines and the software used for volumetric analysis, differences between observers, detecting more fatty liver than expected, hydration status when CT was performed and deviation from the designated liver cutting line were put forward as possible reasons for this discrepancy.

Yoneyama et al. suggested that $1 \mathrm{~mL}$ liver volume in cirrhotic livers equals $1 \mathrm{gram}$ of liver tissue, while $1 \mathrm{~mL}$ volume equates to $0.85 \mathrm{~g}$ liver tissue in non-cirrhotic livers (4). Sonnemans et al. measured liver weights during autopsies after performing 3-D CT volumetric analysis of the liver in the early postmortem period, and found a perfect correlation $(r=0.950)$ between actual liver weight and estimated liver volume, and they calculated the liver density as $0.99 \mathrm{~g} / \mathrm{mL}$ (12). They found that age, gender, body mass index, heart failure and hepatosteatosis caused no difference on liver density in this cadaver series of 39 patients (12). Again, in an autopsy study conducted by Jackowski et al., liver density was found to be $1.05 \mathrm{~g} / \mathrm{mL}$ (13). When previous studies in the literature are examined, it is seen that liver den- 
sity has been reported between 0.86 and $1.13 \mathrm{~g} / \mathrm{mL}$ (12). The reason for these differences in liver density may be due to differences in the measurement times of the graft weight (6) because different measurement times were used in these studies such as immediately after the liver graft was removed (bloodfilled), after the blood was drained (blood-free) from the liver, after the perfusion of the graft with preservative solutions, and after the back-table procedures were completed (6). Graft dehydration after perfusion is an important factor affecting liver density (6). In our study, since the amount of blood in the liver was calculated and deducted in the volume measurements calculated with CT, we measured the graft weight after the graft was removed and the blood was drained, and before the graft was perfused.

Zakareya et al. found the formula AGW $(\mathrm{g})=0.92 \times \mathrm{EGV}(\mathrm{mL})$ $+51.48\left(r^{2}=0.651, p<0.001\right)$ in their study (1). Liu et al. found a similar formula - AGW $(\mathrm{g})=0.86 \times \mathrm{EGV}(\mathrm{mL})+72.5\left(\mathrm{r}^{2}=0.9\right.$, $\mathrm{p}<0.001$ ) in their study (5). In another study by Bozkurt et al. AGW ( $\mathrm{g})$ was calculated as $0.843 \times \mathrm{EGV}(\mathrm{mL})(\mathrm{r}=0.834 ; \mathrm{p}=0.001)$ (2). In the study conducted by Kim et al. the mean estimated blood-filled right lobe graft volume was found to be $789 \pm 126.4$ $\mathrm{mL}$, while the mean estimated blood-free right lobe graft volume was $713.9 \pm 114.4 \mathrm{~mL}(14)$. In the same study, the mean actual graft weight was found to be $717.8 \pm 110.4 \mathrm{~g}$, and using the estimated blood-free right lobe graft volume, the formula AGW $(\mathrm{g})=0.88 \times \mathrm{EGV}(\mathrm{mL})+88.5\left(\mathrm{r}^{2}=0.83, \mathrm{p}<0.001\right)$ was determined (14). In the study of Hwang et al., it was suggested that the weight of the blood-filled liver graft was closer to the volume of the right lobe graft estimated by CT (15). Also, Satuo et al. supported this opinion and suggested that blood-filled graft weight correlated more closely with the estimated graft volume (6). These researchers suggested that although the amount of blood in the large vessels of the liver was calculated in volumetric analysis with $\mathrm{CT}$, the amount of blood in the peripheral vascular bed of the liver was ignored (6).

In our study, the right lobe liver graft volumes were predicted with a $97.2 \%$ success rate in the measurements made by the LiverVision $^{\circledR} 3 \mathrm{D}$ semi-automatic CT volumetry software. A positive correlation of $85.6 \%$ was found between EGV and AGW. This relationship was found to be stronger in men $(88.3 \%$ vs $72.8 \%$ ) compared to women, but this may be due to the fact that the number of female donors was almost half of the males (73 vs 35). In order to estimate the actual graft weight, the formula AGW $(\mathrm{g})=0.85 \times \mathrm{EGV}(\mathrm{mL})+124.5\left(\mathrm{r}^{2}=0.732, \mathrm{p}<0.001\right)$ was obtained. As expected, EGV and AGW were found higher in men than in women. We found no significant difference between men and women regarding GRWR and the difference between EGV and AGW. In cases where the GRWR was less than $1 \%$, we considered the possibility of surgeons shifting the resection line to the left lobe to remove a slightly bigger liver graft. Because of this, the difference between EGV and AGW was compared between those with a GRWR of $1 \%$ and above and those with a GRWR of less than $1 \%$, but no significant difference was detected between these two groups. The only striking point was that all measurements made in those with a GRWR below $1 \%$ were determined within the $95 \%$ ranges of agreement.

In conclusion, with the newly developed Turkish semi-automatic LiverVision ${ }^{\circledR}$ software, liver volumes of donors can be successfully predicted with CT in living related liver transplantation. We think that this software can be used safely in calculating the preoperative liver volume for liver donors. As the number of cases increases, it will be appropriate to re-evaluate with the results of larger series.

Acknowledgments: The authors thank to Professor Ayşe Canan Yazıcı Güvercin for the statistical analysis of this study.

Ethics Committee Approval: Istanbul Aydın University Institutional Review Board approved the study protocol on 09.12.2020 (IRB approval number: 2020/313).

Peer-review: Externally peer-reviewed.

Author Contributions: Conception/Design of Study - Ü.Ö., A.D.; Data Collection - Ü.Ö., E.E., D.U.U., M.T.; Analysis and/or Interpretation - Y.T., A.D.; Drafting Manuscript - Ü.Ö.; Final Approval and Accountability Ü.Ö., E.E., D.U.U., M.T., A.D.

Conflict of Interest: The authors have no conflict of interest to declare.

Financial Disclosure: The authors declared that this study has received no financial support

Teşekkür: Yazarlar, bu çalışmanın istatistiksel analizi için Prof. Dr. Ayşe Canan Yazıcı Güvercin'e teşekkür eder.

Etik Komite Onayı: İstanbul Aydın Üniversitesi Kurumsal İnceleme Kurulu, çalışma protokolünü 09.12.2020 tarihinde onaylamıştır (IRB onay numarası: 2020/313).

Hakem Değerlendirmesi: Dış bağımsız.

Yazar Katkıları: Çalışma Konsepti/Tasarımı - Ü.Ö., A.D.; Veri Toplama Ü.Ö., E.E., D.U.U., M.T.; Veri Analizi/Yorumlama - Y.T., A.D.; Yazma - Ü.Ö.; Son Onay ve Sorumluluk - Ü.Ö., E.E., D.U.U., M.T., A.D.

Çıkar Çatışması: Yazarlar çıkar çatışması bildirmemişlerdir.

Finansal Destek: Yazarlar bu çalışmada finansal destek almadıklarını beyan etmişlerdir.

\section{REFERENCES}

1. Zakareya T, Abbasy M, Abdel-Razek W, Abdelkader Salama I, Deif $M$. A novel formula for graft weight estimation from preoperative computed tomography volumetric measurement in living donor liver transplantation. Transplant Technol 2017; 5:1.

2. Bozkurt B, Emek E, Arikan T, Ceyhan O, Yazici P, Sahin T, et al. Liver Graft Volume Estimation by Manual Volumetry and Software-Aided Interactive Volumetry: Which is Better? Transplant Proc 2019; 51(7): 2387-90.

3. Van Thiel DH, Hagler NG, Schade RR, Skolnick ML, Pollitt Heyl A, Rosenblum E, et al. In vivo hepatic volume determination using sonography and computed tomography. Gastroenterology 1985; 88: 1812-17. [CrossRef] 
4. Yoneyema T, Asonuma K, Okajima H, Lee KJ, Yamamoto H, Takeichi T, et al. Coefficient factor for graft weight estimation from preoperative computed tomography volumetry in living donor liver transplantation. Liver Transpl 2011; 17: 369-72. [CrossRef]

5. Lui SA, Bonney GK, Kow WCA, lyer SG, Chang SKY, Madhavan KK. Standard Formulae in Predicting Liver Volumes: A South East Asian series of Adult Living Donors. Transplant Technol Res 2016; 6: 153.

6. Satou S, Sugawara Y, Tamura S, Yamashiki N, Kaneko J, Aoki T, et al. Discrepancy between estimated and actual weight of partial liver graft from living donors. J Hepatobiliary Pancreat Sci 2011;18(4): 586-91. [CrossRef]

7. Heymsfield SB, Fulenwider T, Nordlinger B, Barlow R, Sones $P$, Kutner M. Accurate measurement of the liver, kidney and spleen volume and mass by computerized axial tomography. Ann Intern Med 1979; 90: 185-7. [CrossRef]

8. Kamel IR, Kruskal JB, Warmbrand G, Goldberg SN, Pomfret EA, Raptopoulos $\mathrm{V}$. Accuracy of volumetric measurements after virtual right hepatectomy in potential donors undergoing living adult liver transplantation. AJR Am J Roentgenol 2001; 176: 483-7. [CrossRef]

9. Harada N, Shimada M, Yoshizumi T, Suehiro T, Soejima Y, Maehara Y. A simple and accurate formula to estimate left hepatic graft volume in living-donor adult liver transplantation. Transplantation 2004; 77: 1571-5. [CrossRef]
10. Salvalaggio PR, Baker TB, Koffron AJ, Fryer JP, Clark L, Superina RA, et al. Liver graft estimation in 100 living donors: measure twice, cut once. Transplantation 2005; 80: 1181-5. [CrossRef]

11. Lemke AJ, Brinkmann MJ, Schott T, Niehues SM, Settmacher $U$, Neuhaus $\mathrm{P}$, et al. Living donor right liver lobes: preoperative $\mathrm{CT}$ volumetric measurement for calculation of intraoperative weight and volume. Radiology 2006; 240: 736-42. [CrossRef]

12. Sonnemans LJ, Hol JC, Monshouwer R, Prokop M, Klein WM. Correlation between liver volumetric computed tomography results and measured liver weight: A tool for preoperative planning of liver transplant. Exp Clin Transplant 2016; 1: 72-78.

13. Jachowski C, Thali MJ, Buck U, Aghayev E, Sonnenschein M, Yen $\mathrm{K}$, et al. Noninvasive estimation of organ weights by postmortem magnetic resonance imaging and multislice computed tomography. Invest Radiol 2006; 41(7): 572-8. [CrossRef]

14. Kim KW, Lee J, Lee H, Jeong WK, Won HG, Shin YM, et al. Right lobe estimated blood-free weight for living donor liver transplantation: accuracy of automated blood-free CT volumetry - preliminary results. Radiology 2010; 256: 433-40. [CrossRef]

15. Hwang S, Lee S, Kim K, Park K, Ahn C, Moon D, et al. Correlation of blood-free graft weight and volumetric graft volume by an analysis of blood content in living donor liver grafts. Transplant Proc 2002; 34: 3293-4. [CrossRef] 